\title{
Et portræt af Mary Wigman \\ - de mørke kræfters danserinde \\ Af Helle Winther
}

Og kongen talte:

Du skal danse om dit liv

Slavinde

og hvis din dans

kan tyde livets mening

for mig,

så er du fri.

Så dansede kvinden

den første dans om livet

dansen om de uforløste længsler.

Du kan løsne dine lænker lidt

sagde kongen,

og kvinden

dansede kærlighedens dans.

»Slå hende ikke ihjel endnu«,

råbte kongen.

Derpå dansede kvinden

den vilde dans om lysten,

som sprængte alle lænker,

og overskred alle grænser.

Kongen tildækkede sit hoved:

»Derfor må du dø,

kælling.«

Og slavinderne kom med

dødens sorte slør.

Men danserinden

ænsede det ikke

og dansede bort på det

dansen om lidelse.

Og derpå dansede hun

dæmonernes dunkle dans,

som vækkede alle de kræfter,

som ligger hemmeligt skjult $i$ livet.

Og da dansen var til ende

nejede hun for kongen:
$» J$ eg er parat, herre.«

Og dansede nu

den stille dans om døden.

Atter løftede slavinderne

det sorte sørgeslør op

for at dække hende til

for altid.

Men kongen kyssede

danserindens pande

og sagde:

»Din dans overvandt livet

og overvandt døden.

Lev nu - og vær fri. «1

Mary Wigman fra forestillingen

»Die sieben Tanze des Lebens«.

Frankfurt 1921.

Mary Wigman (1886-1973) blev i 1920'erne det tyske svar på Isadora Duncan (18781927), som grundlagde den moderne dans $i$ Amerika. Mary Wigman udviklede i Tyskland, som den første kvindelige solodanserinde og koreograf en ny dansekunst, der stod i modsætning til ballettens florlette tylsverden. En dans som også arbejdede med de mørke sider af menneskelivet. En ekspressiv dansestil, der er blevet fulgt og udviklet lige siden, og som i 1990'ernes Ny Dans bliver efterfulgt og repræsenteret ved bl.a. den fremtrædende koreograf Pina Bausch.

Følgende er en biografisk skildring af Mary Wigman, med vægt på det grænseoverskridende og civilisationskritiske, som var i fokus i hendes dans. 


\section{Baggrundshistorie}

\section{Maries ustyrlige eventyrlyst}

- I Hannover fødte Amalie Wiegmann d. 13 november 1886 en datter. Den lille Marie blev født ind i et samfund og en tid, hvor kvindens naturlige plads var i hjemmet som hustru og mor. Men den lille Marie havde andre tanker. Allerede som 4-årig bragte hendes eventyrlyst forældrene i oprevet tilstand. En hel eftermiddag var hun forsvundet, og man fandt hende syngende på et af byens fineste konditorier. Det blev ikke den eneste gang, Wiegmann datterens eventyrlyst overskred den gode opdragelses hensigter.

Den unge Marie rejste alene rundt i Holland og Schweitz på trods af moderens $\emptyset$ sker.

Hun havde forbudt den åbentlyst godt begavede Marie at tage en $\emptyset$ nsket stilling, idet en pæn pige hellere skulle se at blive godt gift. Skønt Marie på daværende tidspunkt var klar over, hvilken tiltrækningskraft hun besad overfor det mandlige k $\varnothing$, endte hendes fors $\varnothing \mathrm{g}$ på at leve op til moderens ønsker gang på gang i ulykkelige kærlighedsforhold.

Da hun ved et tilfælde en dag så de $3 \varnothing$ strigske Wiesenthal søstre danse Straussvalsen »Die Blaue Donau «, vidste hun, at hendes skæbne var beseglet. Hendes kærlighedsdrifter susede i blodet, men mod noget andet end det pæne ægteskabelige liv.

$\mathrm{Nu}$ vidste hun, hvad hun ville. Hun ville danse.

Moderen sagde nej, og hendes tidligere lærer sagde: »Kære barn gå hjem og bliv husmor, det vil gøre dig lykkeligere. Der bliver aldrig en danserinde ud af dig. $\aleph^{2}$

Men Marie måtte danse. Det var det eneste hun ville. Og skønt hun med sin kraftige kropsbygning og stærke knogler på ingen måde levede op til tidsbilledet af den dan- sende balletballarina, tog hun skæbnen i egen hånd. På trods af de åbenbare kropslige ulemper og moderens afvisende holdning stak Marie af hjemmefra. Intuitivt fornemmede hun, at dansen var hendes sprog. Ikke balletten, den var »smuk, men ikke mit sprog. Den var søgt og højtravende og ville aldrig have kunnet sige det, som var mit personlige budskab. $\ll^{3}$

Marie opsøgte Wiesenthalsøstrene, som jo var den umiddelbare foranledning til hendes flugt hjemmefra. De afviste hende med en begrundelse om, at hun med sine 22 år var for gammel, men foreslog hende at søge ind som danserinde i en natklub. Marie søgte ind på skolen hos Emile Jacques Dalcroze, og tog med dennes uddannelse i rytmisk gymnastik de første skridt henimod en epokegørende karriere som kvinde, danser og pædagog.

Mary Wigman var født.

\section{Større bevagelsesfrihed til kvinderne}

Mary Wigman blev i 1910-11 skolet hos Emile Jacqus Dalcroze i en politisk og kropskulturel brydningstid. ${ }^{4} \gg$ Das Lebenreformbewegung « var en omfattende bevægelse, som symboliserede et idealistisk oprør mod bl.a. industialiseringens fremmedgørelse og spaltningen af individet i krop sjæl og ånd. »Kultur Statt Zivilisation $\ll^{5} l \varnothing d$ mottoet.

Man søgte en enhed mellem individet, kosmos, natur og kultur. Gennem sund vegetarisk levevis med masser af frisk luft kompenseredes for industrialiseringens forurening. Med en omfattende nøgenhedsbevægelse gjorde man op med tabuet om kroppens forklædning, ikke som et sexuelt oprør, men som et led i den sundhedsfremmende naturtanke. I kølvandet på denne naturlivsideologi opstod også tanker om 


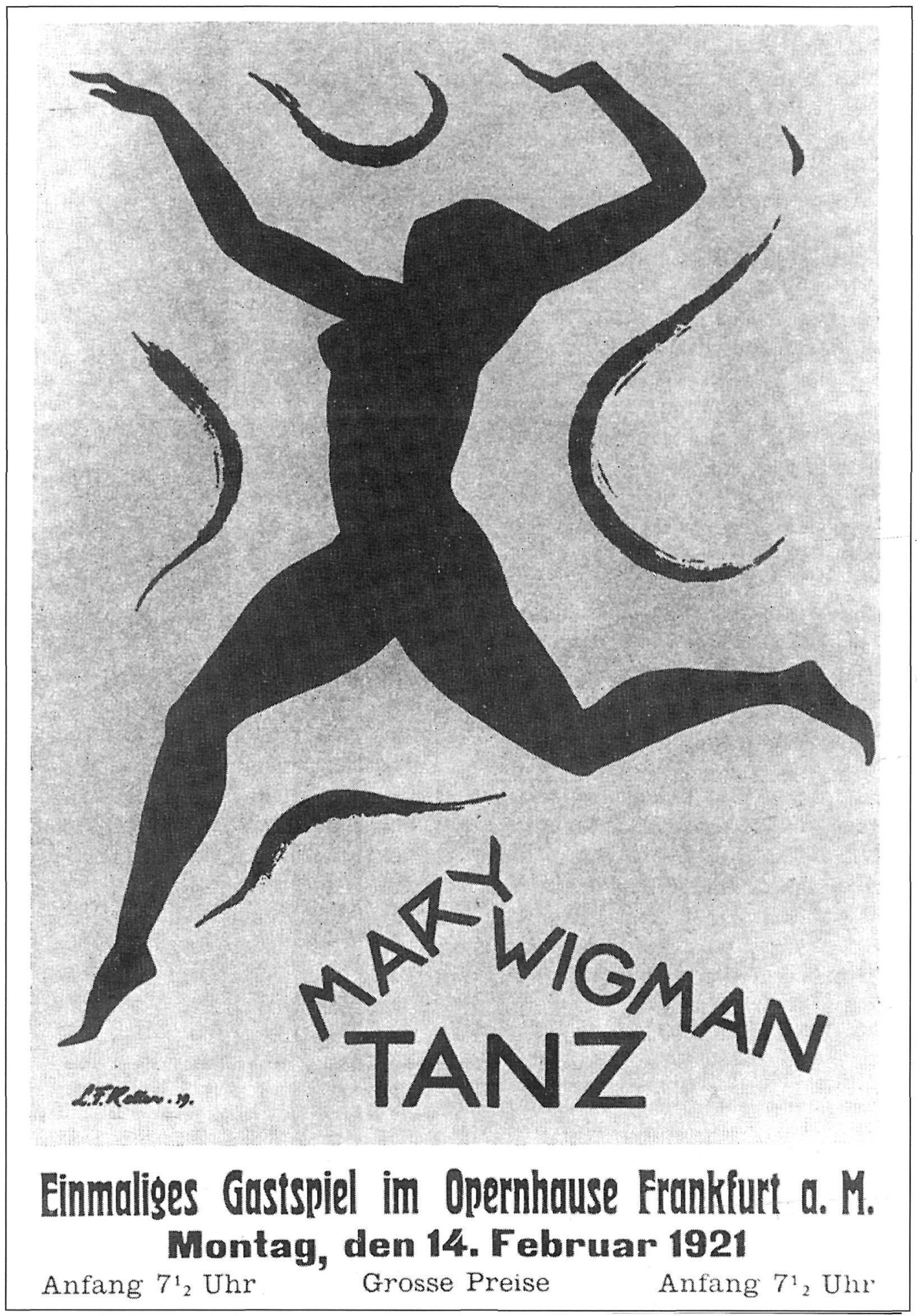


kvindens frigørelse $\mathrm{i}$ en søgen efter den sande naturlige kvinde.

På Dalcroze skolen var man også præget af disse nye sundhedsidealer. De centrale begreber blev her rytme, helhed og kvindelig natur. Rytmen opfattedes som en urkraft, som eksisterede i al natur, hvorfor den var en væsentlig kilde til bevægelses opdragelsen og oplevelsen af det kosmosbegreb, man søgte.

I takt med tidens ånd udviklede Emile Jaques Dalcroze på bagrund af disse tanker et organisk-rytmisk øvelsessystem, som udover at styrke den iboende rytmiske bevægelse også var en søgen efter den kvindelige natur. De studerende kvinder mødte derfor på en gang en ukendt bevægelsesfrihed og en afseksualisering $i$ det naturliges navn.

»I en stor lys prøvesal på Hellerau, fire fem dusin smukke piger. Tyske, amerikanske, franske, russiske. Blonde, sorte, brunhårede piger....(..) De er kun iklædt en sort tricot. Nøgne er deres arme, ben og nakke. Men man tænker overhovedet ikke på deres nøgenhed. Så indforstået er det her. $\ll^{6}$

I disse prøvesale på Hellerau havde Mary Wigman sin gang $i$ to år, indtil hun havde taget sin eksamen. Men allerede på dette tidspunkt havde hun en klar fornemmelse af, at der for hende var en dybere hensigt med bevægelse og dans. Emile Jacques Dalcroze's rytmiske gymnastikøvelsessystem var ikke, hvad hun søgte.

»Dalcroze skolen gjorde ikke så stærkt indtryk på mig, men jeg gjorde, hvad der blev sagt. Så dansede jeg om aftenen i mit værelse for mig selv. « ${ }^{7}$

Efter endt uddannelse modtog hun et brev med tilbud om at overtage og lede en Dalcrozeskole i Berlin. Atter en gang stod hun med sin skæbne i hænderne, og også denne gang valgte hun de usikre uberørte stier frem for den forudsigelige tilværelse. Mary
Wigman ${ }^{8}$ udviklede gennem sin uddannelse og sine ensomme danseaftener sin egen stil. Det brændende $\varnothing n s k e$ om at finde et frit bevægelsessprog vejede for hende tungere end brevet $\mathrm{i}$ hendes hånd.

Hun afslog tilbudet og opsøgte Rudolf von Laban, om hvem hendes ven, den ekspressionistiske maler Emil Nolde (18671956) havde sagt:«Han bevæger sig som Dem, og danser som Dem - uden nogen form for musik. $\ll^{9}$

\section{De eksperimenterende år med Rudolf von Laban}

Rudolf von Laban, hvis bevægelsesanalyse endnu verserer som en uudtømmelig inspirationskilde til bevægelsesudforskning og analyse i England, Tyskland og Danmark, var set med eftertidens øjne en af de største og mest revolutionerende bevægelsespædagoger.

Da Mary Wigman opsøgte ham, var hans ideer om improvisation og bevægelsesanalyser i forhold til Tid, Kraft, Rum og Flow endnu i den første spæde udviklingsfase ${ }^{10}$. Hans visioner om kunstværker som en kombination af dans, musik og poesi drev ham til udvikling. Han havde ideer om at skabe masseoptrin, med forskellige kropstyper og fundamentalt anderledes bevægelsesmønstre end de, som kendtes fra balletten. Det var ideer, som krævede meget udviklingsarbejde.

»For hvordan kunne hans drøm blive til virkelighed, når dansekoret - det væsentligste instrument, han skulle bruge til dette værk, endnu ikke eksisterede? Balletdanserne var ikke egnede til den dans, Labăn forestillede sig. Og den moderne danser var jo endnu ikke født. Laban måtte selv opbygge dette instrument. $\ll^{11}$

Årene med Rudolf von Laban blev for Mary Wigman en tid fyldt med inspiration og 
selvudvikling. Hans ideer om eksperimenterende improvisation stillede store krav til eleverne.

»Han var min lærer, dog ikke i ordets egentlige forstand. Han var den store inspirationskilde, som tog os $i$ hånden og førte os ind $i$ en uigennemtrængelig tykning i junglen. Der lod han os uværgeligt i stikken. Man havde alene kampen om at fægte sig ud igen. Måske var han netop derfor en stor lærer. $\ll^{12}$

Mary Wigman blev »Die Meisterschulerin «, og hun assisterede ham som underviser ved flere lejligheder, og i 1914 fik hun i en bevægelsesforestilling af Laban lov til at bidrage med nogle små solokoreografier på trods af flere mislykkede fors $\varnothing \mathrm{g}$. Det førte til slutningen på en epoke $\mathrm{i}$ hendes liv.

»Mens den fejlfrie præsentation af Labans koreografi gennem den billedsk ønne danserinde kun modtog et svagt bifald, bragede det som en trommeild over min Lento og Hexentanz. Jeg var fuldstændig fortumlet, kunne ikke engang glæde mig over denne uventede succes, snarere følte jeg mig som en forræder mod min partner, som jeg i stedet for at hjælpe måske havde skadet. Mon jeg overhovedet på det tidspunkt gjorde mig klart, at jeg nu siden mit første møde med Laban atter stod ved en skillevej? «13

Laban var overordentligt begejstret for Mary Wigmans succes og spåede hende en stor karriere som danser.

\section{Danserindens første vaklende trin}

Barndomslærerens negative spådom om Mary Wigmans manglende kunstneriske evner var nu gjort til skamme. Hun blev hos Rudolf von Laban, til hun følte sig parat til at tage det store skridt. Så trak hun sig tilbage $\mathrm{i}$ ensomhed på et kursted $\mathrm{i}$ Schweitz og begyndte at eksperimentere.

»Jeg arbejdede i det fri, og som den store Isadora troede jeg på, at jeg måtte være så ubeklædt som muligt også uden strømper og sko. $\ll^{14}$
Hun dansede $\mathrm{i}$ ensomhed $\mathrm{i}$ næsten et år. Hun dansede sine menneskelige følelser sorg, frygt, angst og glæde og skabte danse igennem dem. Endelig trådte hun atter offentligt frem. Hun prøvede at sætte forestillinger op i Berlin og andre større byer, men blev kritiseret til skamme.

»Det krævede mod at optræde over for disse så konservative landsmænd. Ingen havde før mig danset på den måde, og mit Berlinerpublikum accepterede ikke min dans som dans. De piftede mig ud. $\ll^{15}$

Men hun ville og blev ved. Og pludselig en dag var det overstået. Den skarpe kritik forstummede, og hun blev anerkendt som en stor danserinde - og mere end det - som nyskabende. $\mathrm{Nu}$ startede en forrygende karriere, hvor Mary Wigman skabte den ene forestiling efter den anden og samtidig åbnede sin egen skole i Dresden.

\section{Ideerne formes}

\section{Die Tanzgymnastik - forløsning gennem kroppen}

Mary Wigmans danse blev alle skabt efter princippet om, at kroppen er så smidigt og fint et instrument, at den kan udtrykke alle følelser. Hvis den skulle kunne udtrykke alle følelsers nuancer, var det nødvendigt først at opdage og styrke kroppen og befri den for sine hæmninger. For at imødekomme denne forudsætning for koreografiskabelsen skabte hun dansegymnastikken Die Tanzgymnastik. Dansegymnastikken blev en modpol til den eksisterende af hende opfattede smertefulde og mekaniserede gymnastik.

»Enhver kan danse. Jeg vil ikke dermed sige, at enhver kan blive en danser. Det kunstneriske blik er vi født med. Men jeg tror, at enhver kan udvide sig med 
dansens nytte og dermed udtrykke undertrykte og halvtbevidste følelser - og så bogstaveligt talt finde et kropssprog. Man behøver ingen let krop, ingen sarte -bøjede fødder ingen stræk og smidige rygbøjninger i den moderne dans. Der er ingen traditionslænker, ingen isnende konventioner, ingen forudfattede ideer. Istedet for at danse et skema som andre har lært os, danser vi gennem dansens rige med vores egen krop. Bevægelse er magi. ${ }^{16}$

Mary Wigman tilkendegiver her klart, at hendes kropsfilosofiske og pædagogiske ideer indeholder emancipationstanker. $\mathrm{Og}$ som for at bortviske erindringsbilleder om den militære kropsdisciplin i den nyligt overståede verdenskrig breder Die Tanzgymnastik sig parallelt med 20'ernes vilde selskabsdans. Som kropslige symboler på den nye frihed, og samtidig med reformog nøgenbevægelsens forlængede arm formes en kritik mod civilisationens og industriens funktionelle kropsbeherskelse. Kulturkritikere mente dog, at denne modstand forblev overfladisk i modsætning til den nye dansekunst, som også spredtes fra Mary Wigman. ${ }^{17}$ Hendes Ausdruckstanz var for alvor ved at tage form.

\section{Die Ausdruckstanz}

Mary Wigman kan med udviklingen af sin Ausdruckstanz siges at være på forkant med den kulturelle udvikling. Hun var et talerør for avant-garden i sin tid og blev måske netop derfor »pludselig « anerkendt.

For selvom kimen til hendes dans og filosofi blev lagt på kurstedet i Schweiz før og under 1 . verdenskrig, var tiden ikke moden til at sprede ideerne for alvor før starten af 20 'erne.

Ausdruckstanz var præget af ideerne fra Emile Jacques Dalcrozes rytmik og gymnastik, fra Laban, fra den nye psykoanalyse og fra ekspressionismen.

At de ekspressionistiske tanker også inspirerer dansekunsten skyldes måske, at
Mary Wigman er blevet inspireret af vennen, den ekspressionistiske maler Emil Nolde. Den ekspressionistiske kunstform så det som sin opgave at lægge det permanente spændingsfelt mellem indre og ydre verden åbent. Det modsætningsfyldte skulle gøres synligt. Naturen skulle ikke mere reproduceres, men repræsenteres gennem kunsten.

De kunstæstetiske principper i den ekspressionistiske kunst konkretiserede sig for Ausdruckstanz i en fuldsstænding afstandstagen fra ballettens tekniske bevægelsesvokabular. I stedet søgte man som i Die Tanzgymnastik den menneskelige organismes frie bevægelse. Som en modsætning til det hurtigtlevende industrisamfunds skinverden så Mary Wigman og med hende de nye Ausdrucksdansere det som deres lod at skabe kropslige billeder på en vision om en verdensomspændende og tidsuafhængig sandhed om menneskets inderste og subjektive væsen. ${ }^{18}$ At danse »Ausdruck« betød at give sin indre bevægelse en jordisk skikkelse gennem dansen. Derfor varierede udtrykket med de dansendes personligheder og livshistorier. Derfor blev Ausdruckstanz i modsætning til balletten en procesorienteret kunstart, hvor det sjælelige blev drivkraft.

\section{Karligheden og dialogen som paedagogisk metode}

I Dresden dannede Mary Wigman skole. Mange, både mænd og kvinder opsøgte hende gennem kortere eller længere tid. Kærest for hende blev dog en lille gruppe kvindelige dansere, som fulgte hende $\mathrm{i}$ mange år og udgjorde kernegruppen $i$ hendes forestillinger.

I huset i Dresden udviklede Mary Wigman en planløs, og ustruktureret pædagogik, som ikke hældede til nogen form for 
teori - men snarere til intuitionen og hjertet.

»Lærerens opgave er at finde vejen til den lærende, at erkende vedkommendes begavelses karakter og respektere hans eller hendes selvstændige verden. Aldrig tvinge eleven til at udlevere sig selv,- aldrig bruge sig selv som målestok. Læreren må erkende, at kun elevernes aktive medarbejde fører til anerkendende resultater. Det levende dansesprog, som ligger slumrende i enhver ung danser har brug for en levende føring og resonans for at kunne blive vækket og modnet til overbevisende meddelelse.

(..) De nødvendige instrumentelle korrekturer kan og må ikke ske ud fra en alment gyldig anerkendt norm, men ud fra en menneskelig og kunstnerisk forståelse for individet og dets virkelige udtryk. « ${ }^{19}$

I et brev til en ung elev skriver Mary Wigman i 1963:

»Måske skulle man også tale om kærligheden, om ethvert indre beredsskab, som gælder mennesket $\mathrm{i}$ danseren - før man yender sig mod danseren i mennesketden skabning hvor det gærer og syder, der hvor beslutningerne endnu ikke er endegyldigt trufne?«

»Man kunne snarere tale om pædagogisk Eros, om ethvert flukturerende tilfælde, hvor det menneskeligt bevægende og kunstnerisk forpligtende kredser om hinanden $\mathrm{i}$ en levende udveksling mellem elever og lærer i en bestandigt fornyende med og modbevægelse omkring det centrum, som i vores tilfælde hedder dans. $\ll^{20}$

Mary Wigmans pædagogik træder her med det klare budskab om lærerens personlige involvering og undervisningsformens dialogiske fremtrædelsesform tydeligt frem som en modtendens $\mathrm{i}$ forhold til tidens fremherskende »sorte« pædagogik. Men hendes pædagogik udvikledes ikke kun af idealistisk instinkt, men også af kunstnerisk og pædagogisk nødvendighed. Forløsningsprocesserne fra civilisationens slør krævede en medrivende troværdig og tryghedsskabende personlighed som forbillede.

\section{Grupperraseri og dansebesattelse}

For Mary Wigman var forløsningsprocesserne en nødvendighed. Før hendes elever var forløst fra civilisationens grænselag, kunne hendes visioner om det indre urmenneskes kropsfortællinger ikke blive til virkelighed. Helt så nemt har det dog ikke været at finde frem til dette urmenneske $\mathrm{i}$ sig selv. Det læses af Arthur Michels artikel $\mathrm{i} \gg$ Die Vossiche Zeitung ${ }^{21}$ 29. juni 1923. Her forsøger han som en af de første at give en beskrivelse på Mary Wigmans arbejdsmetode. Han beskriver, hvordan hendes før næsten ukendte navn, nu pludselig er på alles læber. Men publikums øjne er, siger han, ikke $\emptyset$ vede til at forstå dette nye kropssprog. Synssansen var hos 20'ernes Berlinerpublikum ikke indstillet til at opfatte sådanne kropsudtryk, hvorfor også deres manglende referenceramme til at forstå denne form for dans i første omgang fører til en forvirret følelsesreaktion. Det kræver $\emptyset v e l s e$ at være tilskuer til denne nye kunstform. Også tilskueren skal udvikle sig og frigøres fra intellektuelle hæmninger, som Mary Wigmans elever kropsligt oplever det i dansesalen.

Arthur Michel refererer til en samtale, han har haft med Mary Wigman, hvor hun har fortalt om den store udfording, det er at befri eleverne fra hæmningerne.

Her står gruppen centralt, mener hun. For kun en gruppe lader sig føre fra øvelse til øvelse gennem nøje tilrettelagt gruppeproces indtil det såkaldte grupperaseri ${ }^{22}$ opstår.

Når således den indbyrdes kemi forfører hver enkelt til upåagtet at kaste den ene intellektuelle hæmning efter den anden overbord, opstår den så forkætrede rus. Dansen besætter danseren, med en frigørende energistrøm, som udgør forskellen på en danseglad dilettant og en ægte danser. 
Når den ekstatiske tilstand er opdaget, er eleverne nok nået langt, og dog er det først her, udforskningen begynder. Først her kan mesterindens visioner begynde at tage form, først her kan de dansende for alvor begive sig ind i det uopdagede ubevidste landskab af dionyssisk rus og dæmoner, som kendetegner Mary Wigmans danseskikkelser. Som en rejse gennem det ubevidste, som tidens store psykoanalytikere C.G. Jung (1875-1961) og Siegmund Freud (18531938) er ved at udforske gennem psykoanalyse, giver hun på dansescenen de arketypiske figurer en kropslig form og fortolkning.

\section{Dans med damoner}

»Den nye dans var ikke ballettens lette flimrende, lyse svævende univers, men en udtryksform, som steg op fra en dunklere verden og symboliserede det tragiske, dæmoniske, stille og svære, og den kæmpende menneskesjæls smertelige lidelse i verden. $\ll^{23}$

Lige fra debutdansen »Hexentanz« i 1914 var det mørke, dæmoniske og ekstatiske et gennemgående tema i Mary Wigmans dansekarriere. Hun beskæftigede sig i sine danse med et bredt spektrum af det menneskelige symbolunivers, men fascinationen af de voldsomme, lidende sider af livet fyldte meget. Kampen med dæmonerne repræsenterede menneskets kamp med sig selv - med undertrykt lyst og angst, med det hun opfattede som instinktivt, destruktivt og dyrisk. Men også ekstasens ubændige lyst stammede ifølge Mary Wigman fra disse ubevidste tilstande. ${ }^{24}$

Heksen som symbol på kvindens eller menneskets magiske, groteske, onde og oprørske sider genoptog hun igen i 1926 i forestillingen »Zur Gestaltenreihe Visionen $\ll^{25}$ og i forstillingen $»$ Frauentanze « fra 1934. Hendes egen natlige transformation til heksegestalten beskriver hun her:
»Da jeg en nat kom tilbage til mit værelse, mødte mit blik spejlet. Det sendte billedet af en, der var vild og besat i kaos tilbage - frastødende og fascinerende. Håret var rodet, øjnene sunket dybt ind i deres huller.

Der var hun - heksen - det jordnære væsen, hæmningsløst instinkt og umætteligt livsbegær,- dyr og kvinde på en gang.

Jeg gruede for mig selv, jeg gruede for at prisgive mig til den side af mit Jeg, som jeg endnu aldrig hav-' de udleveret mig selv til i en så utilsløret nøgenhed.

Men er der, når alt kommer til alt, i ethvert hundredeprocent kvindeligt væsen ikke også et stykke forbudt heks - ligegyldig hvilket format denne urbestand end måtte have? «.«26

Det daemoniske optrådte også som den fortrængte djævelskab i hendes arbejder, bl.a. i » Ein Tanzmarchen« i 1925, og i »Tanz des Dämons« fra »Die sieben Tanze des Liebes« i 1923.

I denne forestilling lod hun dæmonen tale:

»Jeg var

jeg er

jeg vil blive.

På en dag i dit liv

blev jeg dig bevidst.

Skikkelsesløs fløj jeg gennem

verdensrummet.

Men du husede mig.

Gav mig den form, hvori jeg nu lever i dit liv

Jeg er dig nær.

Hvorfor frygter du mig da?

Er jeg ikke ven?

Er jeg ikke formidleren mellem intet og væren?

Hvad skræmmer dig ved billedet af din egen fantasi?

(..)

Jeg skænker dig af det liv i årerne, som mennesket ellers dør af, hvis ikke dæmonen afværger det. Du vil aldrig mere være uden mig. Og vil du savne de mørke stunder, 
hvor dine øjne lærte at se dobbelt?

Da mine kræfter trængte igennem dig?

Du var engang med elementet?

Kære-

Gruens smil om dine røde læber $g \varnothing r$ mig tørstig.

Jeg nærmer mig dit varme blod.

Nu er jeg dig ganske nær.

Mærker du, hvordan mine lemmer

holder dig fast omslynget i en

usynlig dans?

Jeg var,

jeg er,

jeg vil blive,

for dig

med dig

efter dig

uforgængelig. $\ll^{27}$

Dansen til det dæmoniske var uhæmmet grotesk, den blev danset ganske dybt, så danserinden syntes sunket halvt i gulvet. Hun rejste sig kun i en fortvivlet søgen med overvældende bevægelser og skridt. Danserinden forlod rummet under denne søgen, så dansen fremstod uden egentlig afslutning. ${ }^{28}$

Det magiske princip optræder også flere gange figurligt i Mary Wigmans koreografiske værker.

Det mørke symboliseret ved lidelse, klage, skrig optræder ofte i forestillingerne som små koreografiske indslag som i f.eks $»$ Tanz des Leides $\ll^{29}$ og $»$ Klage $\ll^{30}$

$D \not d e n$ som livets endegyldige modsætning var for Mary Wigman en stor besættelse i hendes tanker og arbejder. Hun oplevede døden tale til sig, som den store endegyldige lov, der er fælles for alle mennesker. ${ }^{31} \mathrm{I}$ mange forestillinger optræder dødselementet som forskellige koreografibetegnelser.
$»$ Tanz des $\operatorname{Todes}^{32}, »$ Tanz in den Tod «, ${ }^{33}$ $»$ Todesruf $\ll^{34}$, »Totenklage $\ll^{35}$ og endelig i forestillingen $»$ Das Totenmal $\ll$. Forestillingen »Das Totenmal« udløstes af et længe næret $\varnothing n s k e$ hos Mary Wigman om danserens fuldstændige transformation til det mørke, og makabre. Derfor lod hun fremstille masker til denne forestilling. I $\gg$ Das Totenmal « optrådte en dyreagtig figur som symbol på det aktive princip over for døden, og mellem disse to solistiske eksponenter bevægede en gruppe larvelignende væsener sig som afsjælet liv i kløerne på det aktive princip: dyret. ${ }^{36}$

Dansen var båret af kraftfulde bevægelser og en kamp mod vanviddet og døden understøttet af skrig og paukertrommer.

Lysten og ekstasen optrådte som den paradoksale modsætning til det mørke og skæbnesvangre og dæmoniske i f.eks »Feuertanz $\ll$ og »Tanz der Lust « fra »Die sieben Tanze des Lebens«. Som koreografiske afspejlinger af den vilde rus $i ø$ velsessalen forsøgte Mary Wigman altså også, som modsætning til civilisationens appolinske spændetrøje, men i tråd med tidens kulturelle frigørelsestrang, at offentliggøre dette tema.

$»$ Tanz der Lust « blev danset til gongonger og trommer.

»Så pludselig et skrig fra gongongen, trommerne rasler, lyset falder skærende og heftigt henover rummet. Danserinden styrter ind, hun flygter med store spring. Som tusinde sukkende flammer hvælver den skærende lyse kappe sig, hun lader sig fange i de løse led tumler forvirret rundt i spring.

Trommen raser vilde rytmer, gongongen hyler .

Danserindens krop raser og blusser i selvfortærende hede. Danserinden omkredser danserummet med store spring. Hun nærmer sig spiralisk rummidten og slutter løbet af med en koncentreret kropsstilling.

Dansens karakter er vildt og lidenskabeligt liv. $\ll^{37}$

Med skildringerne af disse ubevidste og som oftest skjulte sindstilstande og krops- 
fornemmelser afdækkede Mary Wigman ikke kun noget almenmenneskeligt - hun forholdt sig også provokerende nytænkende til sit eget $k \varnothing n$.

\section{Forholdet til kфnsroller og politik}

\section{Kvindekunst}

\section{- en hermafroditisk kunstaestetik ${ }^{38}$}

Med Mary Wigmans Ausdruckstanz fik Tyskland en ny dansekunst, som ikke kun var præget af sin særegenhed og modsætning til ballettens florlette tylsverden. Mary Wigman og hendes Ausdrucks-dansere, hvoraf flere senere blev berømte koreografer og danseterapeuter, havde for de flestes vedkommende et væsentligt fællestræk: De var kvinder.

Indtil Mary Wigmans gennembrud havde man i Tyskland kun oplevet få selvbestemmende kvindelige koreografer, som offentligt stod frem på scenen med selvkomponerede værker. Den $\emptyset$ strigske danserinde Grethe Wiesenthal, som var den umiddelbare foranledning til Mary Wigmans flugt hjemmefra, havde allerede ved århundredeskiftet lagt kimene til en ny kvindelig selvforståelse på det dansemæssige gebet.

Men de to amerikanere Isadora Duncan og Ruth St. Denis (1877-1967) havde med deres gæsteoptrædener for alvor vendt danserindebillederne på hovedet og banet vejen for de kvindelige koreografer.

Mary Wigman blev det tyske svar på Isadora Duncan.

Med hende blev de dansende kvinder til mere end marionetter for en mandlig koreografs udtænkte trin. De blev til noget andet en voyeristiske svar på det maskuline køns kvindebilleder.
De ville selv.

De ville ikke bare danse og skabe selv, de ville også danse om sig selv. I dansene gjorde kvinderne sig selv og deres liv til gennemgående temaer - dog med den klausul, at der skulle være en almen værdi i koreografien. Således bliver Ausdruckstanz ikke kun kvindekunst, fordi den er startet af en kvinde, omhandler indre kvindeliv og benytter sig af kvindelige kaotiske rumformningsprocesser istedet for ballettens retlinede og logiske konstruktioner. Mary Wigman så i takt med tidens ideer om den naturlige kvinde også i dansen en form for kvindefrigørelse.

»Jeg tror, at der i alle unge kvindelige mennesker39 i dag er en stærk sund glæde over at bevæge sig levende. Jeg tror også, at der er en stor berettiget egoisme, til først at søge sig selv, før man sætter sig op mod verden og omverden. At søge sig selv, at mærke sig selv, at leve sig selv.

Dansen er i bedste forstand blevet kvindearbejde, for den passer til kvindens væsen. « $\ll^{40}$

Ausdruckstanz kan dermed siges at have haft en kønspolitisk erkendelsesfunktion. Gennem dansen, rusen og iscensættelsen kunne danserinderne opleve og sanse sig selv i en berettiget egoistisk personlighedsudvikling. I forestillingsregi blev denne erkendelsesfunktion mest tydelig $\mathrm{i} \gg$ Frauentanze « fra 1934, hvor både moderen, seersken, og heksen symboliserede de kvindelige understrømme. Måske var det derfor, man aldrig så Mary Wigman med en mand på scenen, som det ellers var kotume ifølge dansetraditionen. Hun koreograferede en del pas-des-deux'er, men dansede altid selv solo. Walter Sorell, Mary Wigmans nære ven, beskriver hende som en kvinde, hvis stærke kunstneriske udstråling intet forfinet og sart havde over sig. Derfor behøvede hun ingen hård, stærk mandlig komponent som modvægt. Hendes stærke knoglebyg- 


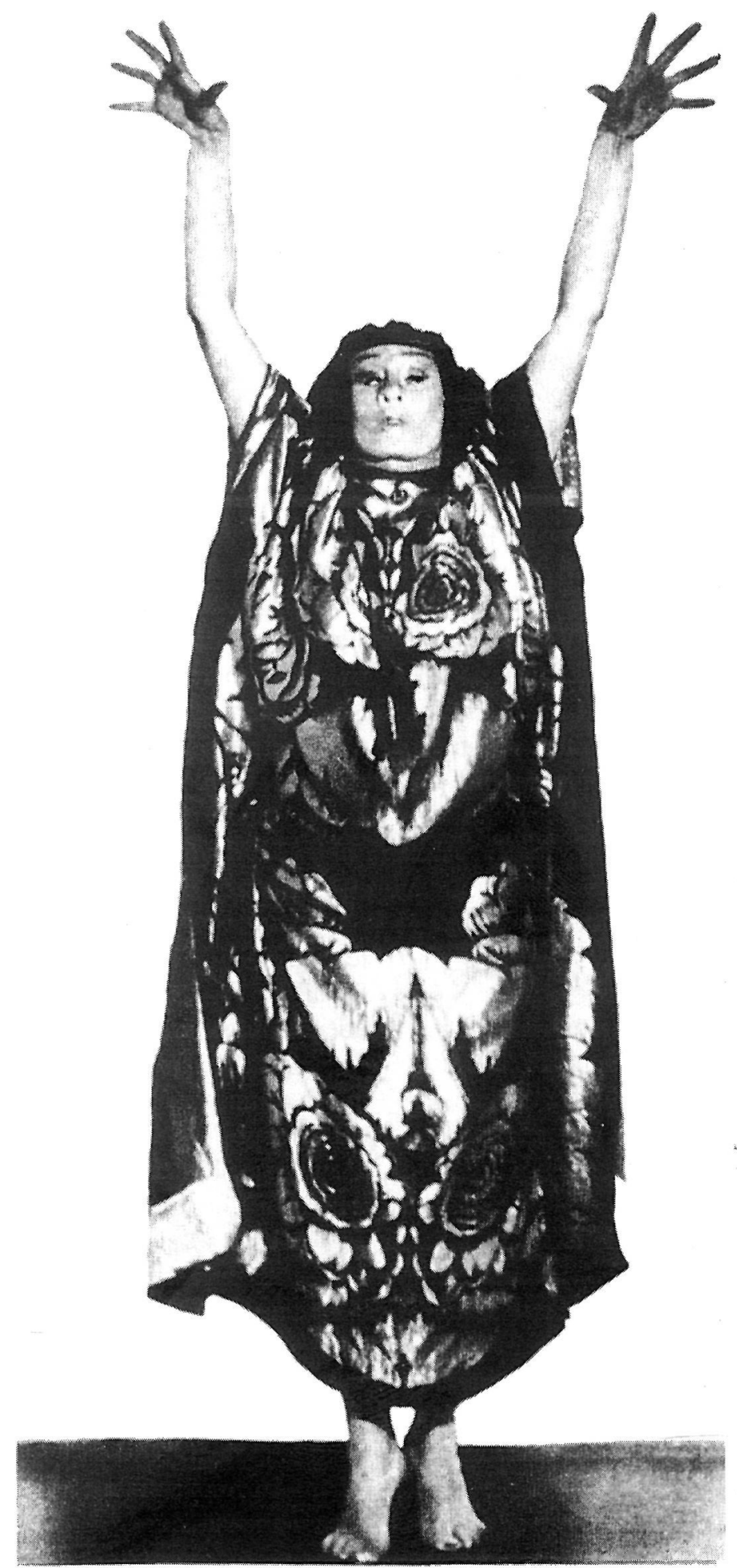


ning var ifølge ham den biologiske forudsætning for udviklingen af hendes - helt ubevidste - hermafroditiske kunstæstetik. ${ }^{41}$

\section{Mфdet med nazismen ${ }^{42}$}

Bortset fra de kvindefrigørende tanker var Mary Wigmans Ausdruckstanz snarere præget af oprørske tanker mod civilisationen som overordnet abstrakt begreb end af modsætningsforhold til den konkrete politiske verden. Inspirereret, som hun var af »Die Lebensreformbewegung «, lå der, som tidligere omtalt, bag alle de ideologiske ideer en politisk utopi i en higen efter det ægte, naturlige og oprindelige i mennesket, en forestilling om et harmonisk liv i balance med kosmos. Alligevel blev såvel Mary Wigman som Rudolf von Laban og mange andre fascinerede af de spirende nazistiske tanker. Måske så de i nazismens drømme om det arketypiske og sande Tyske en parallel til deres egne ideer.

Rudolf von Laban skrev :

$» \mathrm{Vi}$ vil sætte vores udtryksmiddel og vores spændte krafts sprog i tjeneste til den opgave, som fylder vores folk, og hvortil vores Fører med urokkelig klarhed viser vejen.«43

Dansen skulle altså stå i Førerens tjeneste til en forståelse for den tyske ånd.

Mary Wigman skrev i 1935, at det kun var naturligt, ${ }^{44}$ at man i en søgen efter det oprindelige Tyske også indlemmede kunsten. I 1936, da man i patriotisk tummel endnu troede på »Das grosse Deutschland «, arrangerede Rudolf von Laban en stor massescene som festspil ved »Die Jugend Olympiade «. Hans oprindelige ide om »Die Laientanzbewegung «, som troede på det almindelige menneskes frigørende bevægelsespotentiale, blev her ommodelleret til massemanipulation i nazismens tjeneste. Mary Wigman koreograferede til lej- ligheden - ironisk nok - sin »Totenmal.« På samme tid oplevede de, hvordan landet voksede, den sociale nød aftog, arbejdsløsheden svandt ind.

Men allerede på det tidspunkt var fremtrædende personligheder begyndt at flygte, heriblandt fysikeren Einstein, og forfatterne Thomas Mann og Ernst Toller.

Indtil 1937 troede Mary Wigman på, at hun som upolitisk kunstner kropsliggjorde almenmenneskelige problemer gennem dansen.

I sommeren 1937 kom det store realitetschock. Rudolf von Laban blev anklaget for at have haft jødiske elever og blev udvist. Hans skæbne blev forskånet for en afslutning i koncentrationslejr, men han blev svært afkræftet udvist til Frankrig.

Oprindeligt kunne nazisterne bruge Rudolf von Labans og Mary Wigmans evner til masseiscenesættelse, men på den anden side blev alle individualistiske og ekspressionistiske kunstnere krævet undertrykt og fordømt. Også Mary Wigmans kunst begyndte at blive »uønsket«. Hun havde haft to jødiske elever, og hendes skole i Dresden havde altid haft dørene åbne for alle slags nationaliteter. Hun havde desuden ombygget skolen for jødiske penge. To af hendes betroede medarbejdere Gretl Curth og Hans Hastig vendte sig mod hende og blev til intriganter og anklagere. Hendes skole blev sat på sultestøtte, og hun skabte i årene 1937-42 kun to værker, som gav genlyd. »Tanz der Niobe « var en stille dans en protest mod hendes tid og medmennsker. Denne kvindeskikkelse fra den græske mytologi blev et symbol på de lidende kvinder og mødre, hvis sønner og mænd forsvandt eller gik døden i møde på slagmarken.

»Jeg har i disse dage set så mange kvinder på gaderne. Kvinder, kvinder, kvinder overalt, for mændene 
var væk. Kvinderne ventede, ventede, ventede på deres mænd og på deres sønner. De måtte give dem væk, som de havde givet livet til. Der var så mange, som ikke kom tilbage. Jeg måtte lave noget til det om det, måske kun for at blive fri for mine egne følelser. $\ll 5$

I 1942 blev trykket fra det nazistiske styre og hendes egen fremtrædende alder udslagsgivende for hendes endegyldige beslutning om at træde tilbage som solodanserinde.

Hun kreerede som et sidste soloværk »Abschied og Dank «, og flygtede derefter med ryggen til den skole, som efter 22 år intenst arbejde såvel symbolsk som konkret var brudt sammen.

Min historie slutter her, men efter krigen satte Mary Wigman gruppeforestillinger op, og ledede til sin død i 1973 Wupperthaler Tanztheater, og fungerede i øvrigt som lærer i Berlin.

\section{Det granseoverskridende hos Mary Wigman}

At Mary Wigman stod som en til tider provokerende fornyer i sin tid, er der ingen tvivl om. Hun var et velbegavet og kunstnerisk bredt funderet menneske. Hendes kraftige knoglebygning stod ikke kun på scenen som et markant tvekønnet manifest på en stærk kvindelig skaber. Også i pædagogiske sammenhænge turde hun det grænseoverskridende. Men hvori bestod det grænseoverskridende hos Mary Wigman?

Temaet udmønter sig på flere forskellige forståelsesniveauer, som på trods af deres opsplitning betydningsmæssigt er indvævede i hinandens mønstre.

\section{Det astetiske}

2. Det civilisationskritiske

3. Det kфnslige

4. Det psykoanalytiske
5. Det identitetsudviklende set $i$ en samfundsrelateret kontext

På det cestetiske niveau var Mary Wigmans Ausdruckstanz provokerende og fornyende.

Hun brød allerede i starten af sin karriere med den romantiske ballet, som havde styret scenen siden slutningen af 1800 tallet. Den klassiske ballet stod med sine rette linier og kontrollerede, harmoniske og florlette kroppe for et æstetisk ideal. Gennem den strenge dansetræning udvikledes næsten uforståelige springteknikker, som sammen med tåspidsskoene og de uskyldsrene ballerinaer understregede symbiosen med det åndelige.

Mary Wigman tilføjede en ny dimension til ballettens kendte og ordentlige arbejdsform.

Kaos og improvisation blev for hende vigtige arbejdsmetoder. Hun nægtede som den store Isadora Duncan at bruge sko, og smed dermed i dansen på de bare fødder et symbolsk panser væk i en søgen efter noget nøgent og oprindeligt.

Hun valgte $i$ sine temaer at erstatte ballettens brusende tylssk $\varnothing r t e r$ og overjordiske temaer med dæmoniske skikkelser, og maskedanse om Døden. Hun kan dermed siges at have lagt kimen til et brud med den traditionelle opfattelse af æstetikken som læren om det skønne. Hos Mary Wigman fremstod også menneskets mørke sider som et ligeværdigt æstetisk produkt.

For hendes publikum virkede dette grænseoverskridende. I starten så meget at hun blev skarpt kritiseret. Senere kom de strømmede til i tusindtal. Det før så provokerende var blevet til forløsning for øjet. En pirrende oplevelse af envejskommunikation i teatersalens mørke.

$P a ̊$ det civilisationskritiske niveau er hun grænseoverskridende via normkonfrontati- 
onen mellem den ydre verden og blottelsen af menneskets inderste.

Desuden finder hun sammen med de $\varnothing$ vrige tendenser i tiden et bud på det »naturlige « og »ægte. « At lede efter det naturlige og ægte kræver naturligt grænseoverskridende handlinger, hvis civilisationens ham skal skrælles af. Disse normoverskridelser fandt hos Mary Wigman sted i hendes intuitive pædagogiske verden i Dresden, hvor hun gennem masseraseri og ekstase fik fremtryllet den magiske energistrøm, som var så vigtig for hendes dans. Det civilisationskritiske element indskrænkede sig dog ikke kun til forløsning i dansesalen, men strakte sig videre ud i en normkonfrontation med den kulturelle virkelighed ${ }^{46}$. Denne kritik var måske nok ikke planlagt af hverken Mary Wigman eller andre, som inspireredes af hendes Ausdruckstanz. Ikke desto mindre udviklede denne underløbende samfundskritik sig gennem 20 'erne - retningsbestemt og stringent.

Som en samfunds- og kulturutopi stod Ausdruckstanz på fronten med en kritik af civilsationens bånd, af det kropsløse og åndeliggjorte og af industrialiseringens truende teknologisering af menneskets vilkår. Med betoningen af det irrationelle, mystiske, kropsligheden og intuitionen kan Ausdruckstanz siges ideelt som socialt at have stillet et kritisk alternativ til industrialiseringens fremtidstegn.

$P a ̊$ det kønslige niveau overskred Mary Wigman allerede som 4-årig på konditoriet en alvorlig moralsk grænse for, hvad der forventedes af en pæn pige. At søge karriere istedet for ægteskab var bestemt ikke almindeligt på trods af tidens kulturelle strømning og søgen efter den naturlige kvinde. Den naturlige kvinde var en romantisk udgave af den kvindelige natur og indbefattede en $\emptyset$ get kropslig frihed i forhold til klædedragt og kropsbevægelse. En politisk frigørelse og ligestillingsspørgsmål på det samfundsmæssige felt var derimod aldrig på tale. Kvindens plads var underlagt en usynlig overenskomstmæssig aftale mellem kønnene. Hendes plads var derhjemme.

Gennem hele sin dansehistorie brød Mary Wigman med normpådragelserne til det kvindelige $k \emptyset n$ og overskred alle forudfattede forventninger og krav. Hun koreograferede selv, iscenesatte kvindelige emancipations- og erkendelsesprocesser gennem dansen, og tillod sig at danse alene på scenen uden mandligt modstykke. Mary Wigmans krop var ikke feminin, let og yndig, men osede af rå, stærk kvindelighed.

Ikke for ingenting skabte hun flere $\gg \mathrm{He}-$ xentanze $\ll$. Som en dansende furie vendte hun normerne på hovedet og bragte en dionyssisk djævelskab ind på dansescenen. I kulturfilosofisk forstand overskred hun århundreders grænse for, hvad det kristne europæiske samfund af moralske grunde kunne tillade det kvindlige $\mathrm{k} \emptyset \mathrm{n}-\mathrm{og}$ kroppen.

$P a ̊$ det psykoanalytiske niveau søgte hun pædagogisk såvel som kunstnerisk hele sit liv ind til det inderste til de ubevidste og fortrængte dele af menneskesindet.

I den klassiske dansetradition forholder danserne sig hele tiden til deres eget og koreografens spejlbillede. Gennem spejlbilledet søges den ideelle »anden «. Spejlet ser kun subjektet fra de mest fordelagtige sider og glemmer, hvad der gemmer sig på bagsiden af spejlet.

Mary Wigman er en af de første, som bryder med spejlets glansbilleder. Hun $s \emptyset-$ ger »den anden « $\mathrm{i}$ sig selv.

I disse processer kan hun siges at overskride JEG'ets grænser. 
I rusen og længslen efter en transformation til denne »anden « $\mathrm{i}$ hende selv billedliggjorde hun og hendes elever gang på gang scenisk skikkelser og skygger fra deres egne glemte og ubevidste livshistorier. Hendes fascinationer af menneskets mørke og uopdagede sider signalerer et skabelsesmiljø mellem mareridt, drøm og ekstase. Hun skaber på scenen mange af de arketypiske figurer, den samtidige psykoanalytiker C.G. Jung ${ }^{47}$ mener hører til i menneskets arkaiske Ubevidste.

\section{$P \stackrel{\text { det }}{\text { identitsudviklende niveau set } i \text { en }}$} samfundsrelateret kontext var Mary Wigman tilsyneladende i de tidlige år upolitisk. Der var ikke tradition for, at kvinder blandede sig i politik, hvorfor hun sikkert også har været en novice på området.

Men spørgsmålet er, om frigørelse af kropslig energi og bevægelsespotentialer kan siges at være upolitisk? Lå der f.eks i de kvindelige kropslige emancipationsprocesser en bevidsthedsforskydning? Lå der en behovstilfredsstillelse, der gjorde, at frigørelseskravene ikke udmøntede sig i ligestillingsteorier, som skulle manifesteres på de politiske scener? Eller dannede de sig selv ud fra et andet menneskesyn end det fremherskende, således at de også reelt omend ikke politisk - fungerede modkulturelt?

I 1936 deltog hun som nævnt i nazistisk propaganda ved »Die Jugend Olympiade $«$. Som en medløber der glemte sine egne intentioner om at være upolitisk? Overskred Mary Wigman her sine egne (og andres?) normer for grænserne mellem politik og kunst?

Muligvis var hun med sin stærke nationalfølelse naivt forblændet af drømmene om det store Tyskland. Derfor blev hun, da hun med Rudolf von Labans udvisning blev vækket af Tornerosesøvnen nødt til at manifestere og integrere sin vågnende politiske bevidsthed i dansen. »Tanz der Niobe« var den eneste forestilling, som havde et åbenlyst forhold til den politiske virkelighed. En stille protest - hvor grænsen mellem kunst og politik lod sig udviske.

\section{Mary Wigmans relevans idag}

\section{Hvad vil Mary Wigman os?}

70 år efter højdepunkterne $\mathrm{i}$ hendes karriere synes hun at være utroligt moderne eller er det os, der er gammeldags?

Hendes filosofi og arbejdsmetoder ligner meget de tanker, som er fremherskende $\mathrm{i}$ den ekspressive kropskultur i dag, og alene de reflektioner, denne spejlingsproces sætter $\mathrm{i}$ gang, skaber et dybdeperspektiveret billede af nutiden.

Men spørgsmålet er, om vi også havde oplevet hende som moderne, hvis vi havde set hende. Vi vil læse hende ud fra vores egen forståelsesramme, men hendes kulturkrop var en anden end nutidens.

Dansen er en flygtig og forgængelig kunstart, derfor kan vi ikke se hende i bevægelse. Bevarede billeder taler deres eget sprog. Nogle taler til 90'ernes opfattelse af 'naturlighed' og 'ægthed', andre forekommer lidt kantede, opstyltede og ufrivilligt komiske. I tankebanerne mødes verdener fra forskellige historiske perioder, men på det kropslige felt danner kulturkroppene indimellem en sprogbarriere. Mary Wigmans danse ville sansynligvis ikke provokere og besætte et stort dansepublikum i dag. Synssansens tolerancetærskeler har alene siden opfindelsen af fjernsynet gennemgået en ekstrem udvikling.

Pina Bausch overtog efter Mary. Wigmans død i 1973 Wupperthaler Tanz Theater. I forlængelse af Ausdruckstanz idealerne har hun siden 1980 givet revolutionerende bud på den Ny Dans. Målet for hende er 
ikke at vise det befriede naturlige menneske. Hun vil vise mennesket med alle dets hæmninger og alle dets slør i en sårbar nøgenhed. I bogstaveligste forstand et opgør med spejlet. Kroppen er kødelig som aldrig før. Nøgne bryster og koekskrementer er del af iscenesættelsen for hele tiden at minde beskueren om menneskets uundgåelige forfald og syndefald.

Der skal meget til for at provokere det toptrænede voyeristiske 90'er publikum.

Men med de kropslige erfaringer er det noget andet.

At sanse og leve sig selv derud, hvor »Der wilder Rausch « opstår kræver også i dag grænseoverskridelser på det personlige og kulturelle plan. På de pædagogiske græsgange skal der hverken koekskrementer eller blod til for at mærke, hvor grænserne går.

Grænser er ikke kun til for at skulle overskrides. Men i arbejdet med den kropslige ekspressivitet vil de uundgåeligt kunne mærkes, og bliver ofte forflyttede i takt med større mod til at åbne for de kræfter, som ligger gemt hos den enkelte.

Mary Wigmans opgør med æstetikken, kønnet og civilisationens normer har sat dybe spor.

\section{Noter}

1. Sorell Walter. Mary Wigman. Ein Vermachtnis. Florian Noetzel Verlag. Wilhelmshaven 1986. S.71-72. Alle citater er oversat af Helle winther.

2. Sorell Walter. s. 23.

3. Wigman Mary i Sorell Walter s.23.

4. Følgende afsnit er inspireret af Klein Gabriele. Frauen Korper Tanz. Berlin 1990. S.123-156.

5. Klein Gabriele s. 135.

6. Hoffmann Camille. Die Tanzerinnen von Hellerau. Neue Freie Presse. Juni 1912. Her fra Klein Gabriele s.149.

7. Mary Wigman sommeren 1970. Her fra Sorell Walter s. 24.

8. Sorell Walter s.34-35.

9. Sorell Walter s. 35.

10. Dette og følgende afsnit er primært inspirerede af Sorell Walter s. 15-55.

11. Mary Wigman i Sorell Walter s. 28.

12. Mary Wigman om Rudolf Laban i Sorell Walter s. 27.

13. Mary Wigman i Sorell Walter s. 44.

14. Mary Wigman i Sorell Walter s. 44.

15. Mary Wigman i Sorell Walter s. 45.

16. Mary Wigman i Sorell Walter s. 48.

17. Klein Gabriele s. 160-180.

18. Her fra Klein Gabriele s. 180.

19. Bach Rudolf. Das Mary Wigman Werk. Dresden 1933. s. 19. Her Fra Muller Hedwig. Mary Wigman Leben und Werk der grossen Tanzerin. Beltz. Quadriga. 1992. s. 77.

20. Her fra Muller Hedwig s. 78.

21. Følgende er en kortfattet gengivelse af artiklen. Her fra Sorell Walter s. 213-214.

22. Gruppenraserei. Artur Michel.

23. Schleusner Thea. Tanzerische Frauenpersonlichkeiten der Gegenwart. In: Die schone Frau. H4 1928/29. s. 12.

24. Her fra Muller Hedwig s. 198

25. Kilde Sorell Walter side 336.

26. Wigman Mary. Die Sprache des Tanzes. s. 41.

27. Fra $\gg$ Die sieben Tanze des Lebens $«$. Her fra Muller Hedwig s. 197-198.

28. Muller Hedwig. Mary Wigman. Leben und Werk der grossen Tanzerin. Beltz. Quadriga.1992. s. 98.

29. Sieben Tanze des Lebens. Sorell Walter s. 335.

30. Das Opfer 1931. Sorell Walter s. 338.

31. Wigman Mary. Die Sprache des Tanzes s. 20-21.

32. Fra Sieben Tanze des Lebens 1923. Sorell Walter s. 335 .

33. Das Opfer 1931. Sorell Walter s. 338.

34. Fra samme. red.

35. Frauentanze 1934. Sorell Walter s. 341. 
36. Wigman Mary i Sorell Walter s. 78-85.

37. Muller Hedwig. Mary Wigman. Leben und Werk der grossen Tanzerin. Baltz. Quadriga. 1992. s. 96.

38. Dette afsnit er inspireret af Klein Gabriele s. 202210.

39. Weiblichen Menschen. Red.

40. Wigmann Mary. Weibliche Tanzkunst. In: Blatter der Staatsoper und der stadtischen Oper Berlin. H.6. 1929. s. 14.

41. Sorell Walter s. 67-68.

42. Dette afsnit er skrevet på baggrund af Sorell Walter s.146-174 og Klein Gabriele s. 197-202.
43. Laban Rudolf. Die deutsche Tanzbuhne. In: Rudolf von Laban und Mary Wigman. Die tanzerische Situation unserer Zeit. Dresden 1936. s. 5.

44. Wigman Mary. 1935. Her fra Klein Gabriele s. 201.

45. Mary Wigman. Interview i Californien i 1958. Her fra Sorell Walter s. 193.

46. Denne tolkning er inspireret af Klein Gabriele s. 194-200.

47. Mary Wigman kendte C.G. Jung, men refererer oftest selv til Nietzsche.

\section{Litteraturliste}

Bataille Georges. Den indre Erfaring. Rhodos. 1972.

Brandenburg Hans. Der moderne Tanz. Georg Muller Munchen. 1917.

Christiansen Jørn Thaning red. Psykologiske teorier. Billes $\varnothing$ og Baltzer.1986.

Damkjær. Noter om dans og gøgl. Upublic.

Dithmer Monna. Mennesket i dansen. Magisterkonferens. Litteraturvidenskab. KUA. 1989.

Elias Norbert og Eric Dunning. Från riddarspel till fotbollscup. Atlantis 1986.

Elias Norbert. State, formation and civilisation. Basill Blackwell.Oxford 1972.

Eriksen Trond Berg. Nietzsche og det moderne. Tiderne Skifter. Oslo 1989.

Jardine Alice. Køn og moderne tider.1989.

Jung C.G. Jeg'et og det ubevidste. Gyldendal. 1987.

Jung C.G. Gesammelte Werke. Neunter Band. Walter Verlag 1973.

Klein Gabriele. Frauen Korper Tanz. Belz Quadriga. Berlin 1990.

Laban Rudolf. A life for Dance. Macdonald and Evans. London 1975.
Laban Rudolf og Wigman Mary. Die Tanzerische situation unserer Zeit. Dresden 1936.

Langer Susanne. Menneske og symbol. Gyldendals uglebøger 1969.

Muller Hedwig. Mary Wigman. Leben und Werk der grossen Tanzerin. Beltz. Quadriga.Berlin 1992.

Mensler Dora. Schonheit deines Korpers. Verlag bei Died und Cion Stuttgart.1923.

Schechner Richard. Essays on Performance Theory. Drama Book Specialists. London 1973.

Schleusner Thea in Die schone Frau. Berlin H4. 1928/29

Sloterdijk Peter. Kritik af den kyniske fornuft. Hans Reitzel 1989.

Sorell Walter. Mary Wigman. Ein Vermachtnis. Florian Noetzel Verlag. Wilhelmshaven 1986.

Steinbeck Dietrich. Mary Wigmans choreograficshes Skitzenbuch. Edition Hentrich. Berlin 1987.

Wigman Mary. Die Sprache des Tanzes. Ernst Battenberg Verlag. Stuttgart. 1967.

Wigman Mary. Weibliche Tanzkunst. Blatter der Staatsoper und der Stadtischen Oper. Berlin 1929. 
